\title{
Asymptomatic partial atrioventricular septal defect patient admitted in adulthood
}

\section{Erişkin yaşta başvuran asemptomatik parsiyel atriyoventriküler septal defekt hastası}

\author{
Veysel Tosun, MD $^{1}$, Necmettin Korucuk, MD $^{2}$, Ünal Güntekin, MD ${ }^{3}$, Yasemin Behram Kandemir \\ $\mathrm{PhD}^{4}$
}

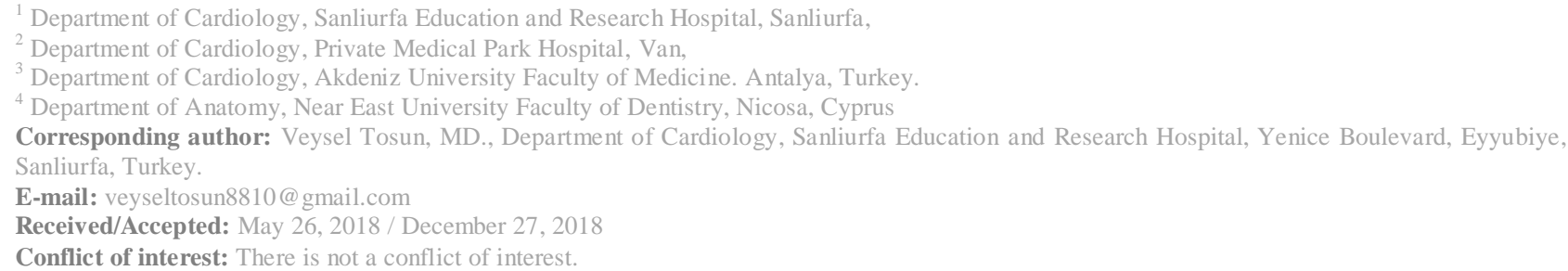

\section{SUMMARY}

Partial atrioventricular septal defect (partial AVSD) is one of the congenital heart diseases. A small number of patients may be undiagnosed until older ages and reach adult life asymptomatically. Only few of those can reach adulthood without timely diagnosis and surgical correction. We report a 36 years old partial AVSD case firstly diagnosed by routine echocardiography that had fatigue and exertional dyspnea for one year. Because of partial AVSD has long term detrimental effects on the right cardiac chambers, the patient was proposed for surgical operation and treated successfully.

Keywords: partial atrioventricular septal defect, echocardiography, adulthood patient, surgical operation

\section{ÖZET}

Parsiyel atriyoventriküler septal defekt (parsiyel AVSD) konjenital kalp hastalıklarından biridir. Hastaların küçük bir kısmı ileri yaşlara kadar tanı almamış olabilir ve asemptomatik olarak erişkinliğe ulaşabilir. Bunlardan da sadece birkaçı zamanında tanı alıp cerrahi operasyon geçirmiş olmaktadır. Son bir yılda yorgunluk ve egzersiz dispnesi nedeniyle istenmiş olan rutin ekokardiyografisi ile ilk defa tanı konulan 36 yaşında parsiyel AVSD hastasını sunduk. Sağ kalp boşlukları üzerinde parsiyel AVSD' nin uzun dönemde zararlı etkileri olmasından dolayı hastaya cerrahi operasyon önerildi ve hasta başarıyla tedavi edildi.

Anahtar sözcükler: parsiyel atriyoventriküler septal defekt, ekokardiyografi, erişkin hasta, cerrahi operasyon

\section{INTRODUCTION}

Partial atrioventricular (AV) canal defect represents part of the spectrum of AV septal defects, including an ostium primum atrial septal defect but with two separate AV rings, no significant interventricular communication and usually a cleft in the anterior mitral valve leaflet. ${ }^{1}$
Patients with complete or intermediate type AVSD rarely survive decades without appropriate treatment, but partial type AVSD patients may be undiagnosed until older ages and reach adult life asymptomatically. Clinical symptoms depend on the ostium primum defect size and the degree of mitral regurgitation. Symptomatic patients are 
operated at 3-5 years old or on early childhood. ${ }^{2}$ Most common clinical findings are impaired exercise tolerance, atrial flutter / fibrillation arrhythmias, shortness of breath secondary to the degree of mitral regurgitation and pulmonary hypertension.

Partial AVSD or known as ostium primum atrial septal defect, usually present at an early age, and only few of those can reach adulthood without timely diagnosis and surgical correction. ${ }^{3}$ Here we present a 36 years old male with partial type AVSD, who was undiagnosed until initial presentation.

\section{CASE}

A 36 years old male admitted to cardiology department with the complaints of fatigue and exertional dyspnea for one year. His past medical history was unremarkable. On physical examination, there was an irregular pulse at 90 beats/min, his blood pressure was 115/65 $\mathrm{mmHg}$, cardiac examination revealed $3 / 6$ pan-systolic murmur on the apical and tricuspid focus. There were no signs of the congestive heart failure. Electrocardiography showed sinus rhythm with approximately 95 beats/minute, right ventricular hypertrophy, right bundle branch block and first degree AV block (PR interval: $280 \mathrm{~ms}$ ), also atrial and ventricular premature beats (figure 1). Chest radiography demonstrated increased pulmonary vascularity, as well as enlarged central pulmonary arteries and cardiomegaly. Transthoracic echocardiography demonstrated a $22 \mathrm{~mm}$ defect at the lower interatrial septum, two separate AV valves with cleft mitral, dilated right atrium and right ventricle, third degree right $\mathrm{AV}$ valve insufficiency and a third degree left AV valve insufficiency (figure 2). Left ventricle ejection fraction was $65 \%$ by Simpsons' method. Coronary angiography and cardiac catheterization were performed to the patient. Qp/Qs ratio was calculated as 1.6 with left to right shunt, right and left atrial pressures both were measured 10 $\mathrm{mmHg}$, systolic pulmonary artery pressure (PAP) was measured $30 \mathrm{mmHg}$, mean $\mathrm{PAP}$ was measured $18 \mathrm{mmHg}$. Pulmonary vascular resistance was calculated as 100 dyne. $\mathrm{sn} / \mathrm{cm}^{5}$. Coronary angiography showed no coronary stenosis. Based on these findings, the patient was diagnosed as AVSD, which was suggested to be of the partial type. The patient was scheduled for surgical operation.

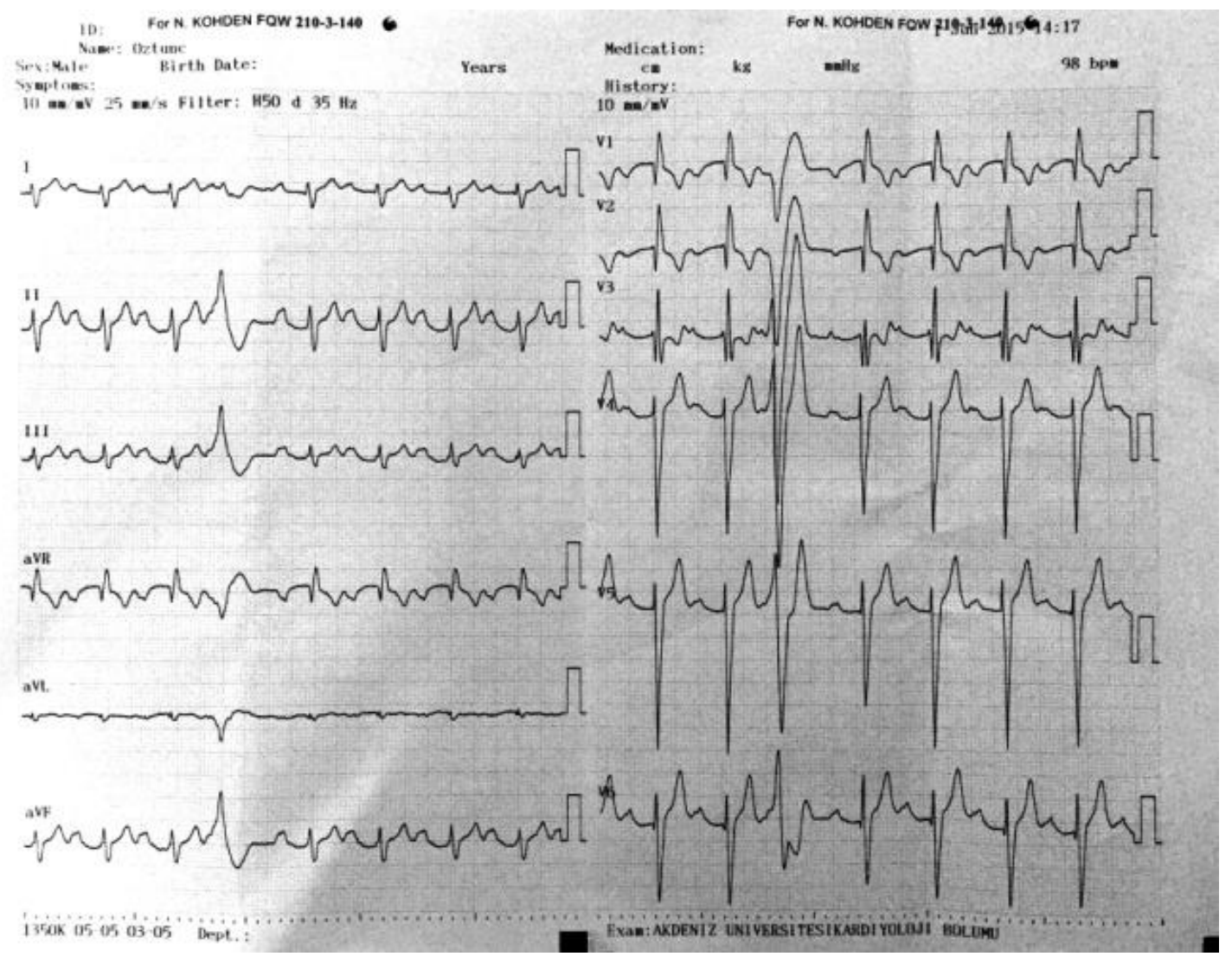

Figure 1: Electrocardiography shows right ventricular hypertrophy, right bundle branch block, first degree AV block and ventricular premature beats. 


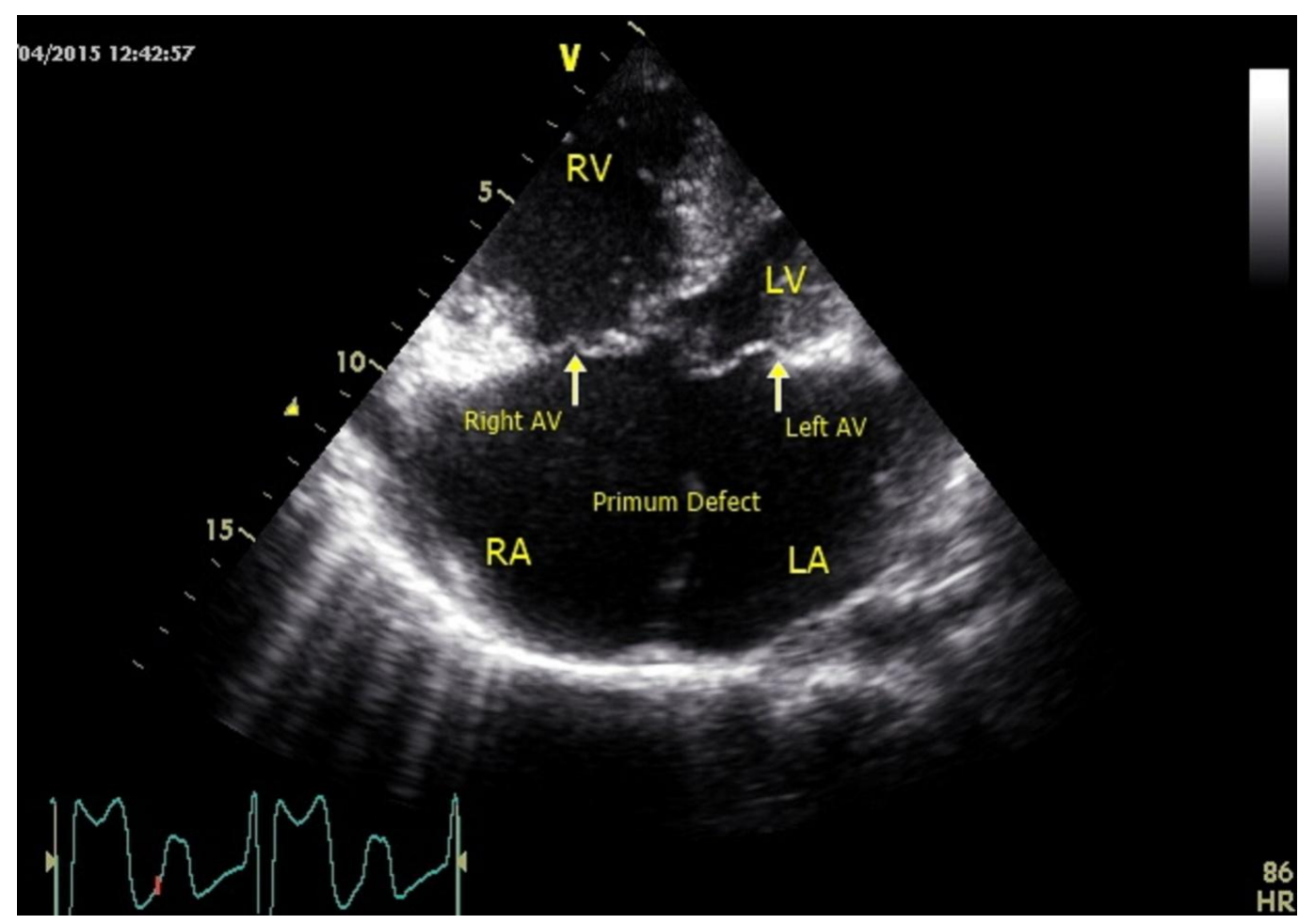

Figure 2: Four-chamber view of transthoracic echocardiography shows a large primum atrial septal defect and two separate AV valve with RA and RV dilatation.

(RA, right atrium; RV, right ventricle; $\mathrm{LA}$, left atrium; $\mathrm{LV}$, left ventricle)

In another hospital, the patient was operated under cardiopulmonary bypass. A $33 \mathrm{~mm}$ prosthetic ring (St. Jude Medical, Saint Paul, Minnesota, USA) was placed in the left AV valve orifice. Because of there was a severe regurgitation in the right AV orifice, de Vega's annuloplasty was performed there. The ostium primum defect was closed with autologous pericardium. He was discharged fifth day after operation. At the seventh day, postoperative echocardiography showed no shunts, atrioventricular valve regurgitation, or stenosis of the left ventricular outflow tract. In one month follow-up the patient was asymptomatic.

\section{DISCUSSION}

Atrioventricular septal defects constitute a group of diseases with incomplete formation of atrioventricular canal formed by the atrioventricular cushions, in the other words incomplete morphological development of the part of atrial septum formed by septum primum, atrioventricular valves and ventricular septum in various degrees. ${ }^{1}$ In partial AVSD patients, usually right and left AV valve annulus has been formed. Although there is an ostium primum type interatrial wide range of defects, there is no any ventricular septal defect (VSD). As it was provided previously, significant numbers of admitted adult patients with AVSD had comorbidities including arrhythmias, coronary heart disease, heart failure, and pulmonary hypertension. In our case report, the patient had ostium primum defect and severe AV valve insufficiency, but he had no VSD or any comorbidity except atrial and ventricular premature beats. ${ }^{4,5}$

Patients presenting with partial AVSD in adulthood are rare. The natural history of partial AVSD without surgery carries a $50 \%$ mortality before 20 years of age and $5 \%$ to $10 \%$ mortality in medically treated $>40$ years old patients. ${ }^{6}$ In partial AVSD patients, a 40 year survival following surgery is $76 \%$ according to the Mayo Clinic reports. ${ }^{7}$ Minich et $\mathrm{al}^{1}$ reported that the median age of repair partial AVSD was 1.8 years, Bowman et $\mathrm{al}^{8}$ reported that the median age of repair partial AVSD was 7.9 years which was older. Additionally, Bowman et $\mathrm{al}^{8}$ suggest that patients operated at a young age (1.5 years) had a worse 5 year overall survival rate. These studies showed that repair of partial AVSD can be safely performed at an older age. More recent studies have reported reoperation rates of $6 \%$ to $28 \%$, and 
left AV valve regurgitation was the most common reason for reoperation in these patients.

Partial AVSD can be repaired safely in the adult population. Operative mortality is low, and survival is well in patients repaired early references before pulmonary hypertension. Mitral valve repair should be used when it is possible; it gives excellent results. In keeping with the findings of other series involving younger patients, functional status usually improves. In our case, pulmonary hypertension had not developed yet, and the defect and AV valve insufficiency had been repaired successfully.

\section{CONCLUSION}

Our patient is one of the asymptomatic, rarely encountered older partial AVSD patients. These patients can be diagnosed easily by echocardiography, so adult cardiologists should be aware of these patients, and keep in mind congenital heart defects in the adult patients.

\section{REFERENCES}

1. Minich LL, Atz AM, Colan SD, et al. Partial and transitional atrioventricular septal defect outcomes. Ann Thorac Surg 2010; 89:530-6.

2. Burke R, Horvath K, Landzberg M, et al. Longterm follow-up after surgical repair of ostium primum atrial septal defect in adults. J Am Coll Cardiol 1996; 27: 696-9.

3. Tandon R, Moller JH, Edwards JE. Unusual Longevity in Persistent Common Atrioventricular Canal. Circulation 1974; 50: 619-26.

4. Rodriguez FH, Moodie DS, Parekh DR, et al. Outcomes of hospitalization in adults in the United States with atrial septal defect, ventricular septal defect, and atrioventricular septal defect. Am J Cardiol 2011; 108:290-3.

5. Opotowsky AR, Siddiqi OK, Webb GD. Trends in hospitalizations for adults with congenital heart disease in the U.S. J Am Coll Cardiol 2009; 54:460-467.

6. Bergin ML, Warnes CA, Tajik AJ, Danielson GK. Partial atrioventricular canal defect: longterm follow-up after initial repair in patients $\geq 40$ years old. J Am Coll Cardiol 1995; 25:1189-94.

7. El-Najdawi EK, Driscoll DJ, Puga FJ, et al. Operation for partial atrioventricular septal defect: a forty-year review. J Thorac Cardiovasc Surg 2000; 119:880-90.

8. Bowman JL, Dearani JA, Burkhart HM, et al. Should repair of partial atrioventricular septal defect be delayed until later in childhood?. Am J Cardiol 2014; 114:463-7. 